\title{
Review
}

\section{Diet Associated with Inflammation and Alzheimer's Disease}

\author{
Maryam Vasefi*, Mackenzie Hudson and Ehsan Ghaboolian-Zare \\ Department of Biology, Lamar University, Beaumont, TX, USA
}

Accepted 18 October 2019

\begin{abstract}
Neurocognitive disorders, such as Alzheimer's disease (AD), affect millions of people worldwide and are characterized by cognitive decline. Human and animal studies have shown that chronic immune response and inflammation are important factors in the pathogenesis of AD. Chronic inflammation can accelerate the aggregation of amyloid- $\beta$ peptides and later hyperphosphorylation of tau proteins. The exact etiology of AD is not clear, but genetics and environmental factors, such as age, family history, and lifestyle are linked to neurodegenerative diseases. Lifestyle habits, such as poor diet, are associated with inflammation and could accelerate or slow down the progression of neurodegenerative diseases. Here we provide a review of the potential conditions and factors that stimulate the inflammatory processes in AD. An understanding of inflammatory mechanisms influencing the development of AD may help to protect against dementia and AD.
\end{abstract}

Keywords: Alzheimer's disease, diet, gluten sensitivity, inflammation, microbiome, oxidative stress

\section{INTRODUCTION}

Due to a globally aging population, the numbers of those living with dementia are expected to grow threefold by 2050 [1], threatening a global dementia epidemic [2]. Alzheimer's disease (AD) is one of the most common types of dementia. The estimated annual costs of caring for $\mathrm{AD}$ and dementia patients will increase from $\$ 307$ billion to $\$ 1.5$ trillion. A delay of $\mathrm{AD}$ onset by 1 to 5 years results in an economic gain of $\$ 183,227$ to $\$ 511,208$ [3]. In addition to economic gain, delaying $\mathrm{AD}$ is beneficial to individual and public health.

$\mathrm{AD}$ is a slowly progressing neurodegenerative disorder that is characterized by plaques of amyloid- $\beta$ (A $\beta$ ) and neurofibrillary tangles which build up in the brain years or even decades before symptoms appear. Brain inflammation associated with aging may lead to increased amyloid plaque and tau tangle produc-

\footnotetext{
*Correspondence to: Maryam Vasefi, Assistant Professor, Department of Biology, Lamar University, Hayes Biology Building, Room 101A, P.O. Box 10037, Beaumont, TX 77710, USA. Tel.: +1 409880 7090; E-mail: mvasefi2001@gmail.com.
}

tion and promote $\mathrm{AD}$. The discovery of inflammatory pathways in the brain has led some researchers to propose that immunological/inflammatory mechanisms play a fundamental role in the development of $\mathrm{AD}$ [4-6]. Evidence suggests that AD patients experience chronic inflammation that is both driven by and enhances the dysregulation of the immune system.

Inflammation caused by disease states, such as obesity, which results in inflammation in the body's periphery, can ultimately lead to the onset of neuroinflammation $[4,6]$. It was once thought that the blood-brain barrier (BBB) insulated the brain from inflammatory insults to the periphery. However, it is now understood that a system of bidirectional communication exists between the peripheral immune system and the brain immune system [7]. In this way, increases in peripheral immune function can upregulate the activity of microglia and astrocytes. Furthermore, during the AD disease state, the BBB becomes leaky due to the accumulation of $A \beta$ peptides around blood vessels [7-12], which may allow inflammatory mediators to infiltrate the central nervous system (CNS) from the periphery. During times 
of peripheral duress, the cytokines tumor necrosis factor- $\alpha$ and interleukin- 6 can cross the compromised $\mathrm{BBB}$ and activate the central innate immune response, resulting in neuroinflammation and increased risk for AD $[4,13]$. Peripheral inflammatory factors can activate immune cells such as microglia and astrocytes in the CNS, which are the major source of cytokines in $\mathrm{AD}[4,14]$. Prolonged neuroinflammation may contribute to the pathogenesis of $\mathrm{AD}[4,5,15]$. Therefore, appropriate treatment of chronic inflammatory conditions helps to prevent the disease.

The impact of dietary factors such as consumption of carbohydrates, vegetable oils rich in omega- 6 fatty acids, and omega-3 fatty acids can have major effects on immune response and inflammation [16-18]. Diet and food-related conditions can cause chronic inflammation, which increases the risk of dementia and AD. A lifestyle that includes a healthy diet and physical activity can protect against cognitive decline and delay the onset of $\mathrm{AD}[16,19]$. In this review, diet and food-related conditions which can cause chronic inflammation that can be linked to AD will be discussed based on their main biological mechanisms of action. The purpose of this review paper is to explore the link between diet and inflammation and its effect on cognitive condition. For data gathering purposes, the PRISMA guideline was used. The initial search strategy identified some $n=1,426$ papers; $n=120$ studies were included after the abstract's screening and $n=47$ articles met the inclusion criteria. A new insight into how lifestyle habits, such as diet, fit into AD pathology through chronic inflammatory response may help to design new strategies to delay the progression of the disease.

\section{VITAMINS}

\section{Vitamin B}

The B vitamins are a group of eight micronutrients that serve as coenzymes in many important biological processes. The specific B vitamins B2, B6, $\mathrm{B} 12$, and folate are involved in recycling the amino acid homocysteine during the cyclic generation of the amino acid methionine. Deficiencies in the amounts of these B vitamins can lead to increases in plasma homocysteine levels [20]. Homocysteine facilitates the generation of reactive oxygen species (ROS), promotes oxidative stress, and increases inflammation $[20,21]$. High levels of homocysteine is one of the risk factors for AD [22]. Vitamins B2, B6, and B12 decrease the level of homocysteine, thus helping to control AD [23]. In a study of 156 mild cognitive impairment patients, Douaud and colleagues demonstrated attenuated gray matter atrophy using high doses of B vitamins over a period of 2 years [24]. The $B$ vitamins appeared to lower the subjects' homocysteine levels, resulting in reduced gray matter atrophy and slower cognitive decline [24]. However, a metaanalysis by Zhang and colleagues found that while intervention groups treated with vitamins B6, B12, and folate often experienced a reduction in homocysteine levels, these reductions were not translated into better cognition [25]. As demonstrated by these two studies, the effects of the $\mathrm{B}$ vitamins on cognition are uncertain. Thus, it is still unclear at this time whether vitamins B6, B12, or folate act as effective preventive or adjuvant treatments for $\mathrm{AD}$.

\section{Vitamin C}

It is well established that individuals with mild cognitive impairment and AD have decreased plasma levels of ascorbic acid [26-29]. Vitamin C, or ascorbic acid, is theorized to hamper AD pathology and neurodegeneration by two main mechanisms: the modulation of oxidative stress and neuroinflammation $[26,30]$. The anti-inflammatory properties of ascorbic acid are mainly attributed to its ability to block the lipopolysaccharide-stimulated production of inflammatory mediators [31], thus suppressing the MAPK and NF- $\kappa$ B systems [26, 32]. In addition, ascorbic acid supplementation reduces the amyloid plaque accumulation in AD mouse models [33-36]. An observational study reported that supplementation of antioxidant vitamins (C and $\mathrm{E}$ ) was linked with decreased incidence and prevalence of $\mathrm{AD}$ [37].

Other beneficial actions include brain protection against glutamate-mediated oxidative stress or excitotoxicity [26, 38]. Excessive glutamate release leads to hyperactivation of N-methyl-d-aspartate (NMDA) receptors and neuronal damage. However, ascorbic acid prevents glutamate-mediated excitotoxicity by inhibiting the binding of glutamate to NMDA receptors [39-41].

\section{Vitamin D}

Vitamin $\mathrm{D}$ is linked to $\mathrm{AD}$ through regulation of calcium homeostasis, $A \beta$ deposition, antioxidant, and anti-inflammatory properties [42-46]. In animal studies, researchers have demonstrated improved cognitive function and reduced amyloid burden in response to vitamin D supplementation [45, 47]. In 
a meta-analysis by Etgen et al. [48], the researchers proposed a nearly doubled risk of cognitive impairment for individuals with vitamin $\mathrm{D}$ deficiency. Furthermore, human genetic studies have demonstrated a clear relationship between overexpression of vitamin $D$ receptors and reduced amyloid- $\beta$ protein precursor expression $[49,50]$. Vitamin $D$ reduces the level of both $\mathrm{Ca}^{2+}$ and ROS by controlling the expression of Klotho/Nuclear factor (erythroidderived 2)-like 2 (Nrf2), regulatory components of the calcium signaling system and redox signaling system. Reduction of Klotho/Nrf2 expression followed by a decline in vitamin $\mathrm{D}$ has been found in age-related cognitive decline in rats [51]. Miller and colleagues reported that vitamin D supplementation for the vitamin $\mathrm{D}$ insufficient adults increase plasma $A \beta_{40}$, particularly in older adults, suggesting decreased brain $A \beta$ [52]. The results from a large population-based study indicate that vitamin $D$ intake in women with vitamin D deficiency show lower cognitive decline compared to the control group [53]. Furthermore, vitamin D as an adjuvant supplement to memantine treatment shows improved cognition among patients with $\mathrm{AD}$ more than memantine alone [54].

\section{Vitamin $E$}

Vitamin E exerts neuroprotective actions by modulating cognition through antioxidant and antiinflammatory activity $[49,55]$. A further study of the rat hippocampus found that vitamin E deficiency enhances $A \beta$ deposition by reducing the expression of genes that code for proteins that indirectly or directly participate in $A \beta$ clearance, such as insulindegrading enzyme [56, 57]. For the first time, Santos and colleagues reported that vitamin E (2000 IU/d vitamin $\mathrm{E}$ or placebo for two years) slows AD progression [58]. Since then, several clinical studies have investigated the efficacy of vitamin $\mathrm{E}$ in AD treatment. However, some of the trials show no benefit [59-62].

\section{Vitamin $K$}

Evidence shows that individuals with $\mathrm{AD}$ often have low serum concentrations of vitamin K [63-65]. Furthermore, geriatric patients that use vitamin K antagonists as anticoagulant medications suffer more frequent cognitive impairment than patients not prescribed these medications [66]. Vitamin K is involved in neuron development and survival through anti- apoptotic and anti-inflammatory effects which are mediated by Gas 6, protein S, and sphingolipids [67]. Vitamin K may decrease AD risk by modulating sphingolipid metabolism, leading to enhanced $\mathrm{A} \beta$ clearance. Sphingolipids are a class of lipid molecules that confer specific characteristics to the membrane, thereby regulating subcellular trafficking and signaling pathways. Sphingolipids can promote the accumulation of $A \beta$ in endosomal and lysosomal compartments [68]. Vitamin K deficiency can decrease the activity of the enzymes that are involved in sphingolipid metabolism, leading to improper sphingolipid metabolism, and ultimately, poor $\mathrm{A} \beta$ clearance and cognitive decline [56]. There is a lack of human clinical trials on the relationship between vitamin $\mathrm{K}$ and improvement in $\mathrm{AD}$.

Despite a promising theoretical basis regarding the antioxidant and anti-inflammatory roles of vitamins, randomized clinical trials have not demonstrated a neuroprotective effect of vitamin supplementation on developing or preventing AD. Vitamin treatment could show an unreliable effect on AD because of differences in 1) the antioxidant and anti-inflammatory effect of vitamins in each person, 2) diet and nutritional status of the patients, 3) progression of the disease, and 4) types of vitamin deficiency of the patients. However, it has been determined that individuals with mild cognitive impairment and $A D$ may have decreased plasma levels of one or more vitamins.

Random treatment of individuals with mild to moderate $\mathrm{AD}$ with vitamin $\mathrm{C}$ and $\mathrm{E}, \alpha$-lipoic acid, and coenzyme Q3 reduced oxidative stress in the brain; however, it did not influence cerebrospinal fluid biomarker related amyloid or tau pathology and also raised the potential issue of faster cognitive decline [69]. Cornelli reported that patients with AD treated with a cholinesterase inhibitor in combination with a low dose of antioxidants (carnosine, coenzyme Q10, vitamin $\mathrm{E}$, vitamin $\mathrm{C}$, beta-carotene, selenium, $\mathrm{L}-$ cysteine, vitamins B6, B9, and B12, and Ginkgo biloba) showed significant improvement [70]. The available evidence is insufficient and does not fully support the role of vitamins with cognitive decline regarding preventing or treatment of $\mathrm{AD}$ and further investigations are needed.

\section{BALANCE OF OMEGA-3/OMEGA-6 FATTY ACIDS}

The imbalance of omega-3/omega- 6 fatty acids in the typical Western diet sparks harmful peripheral 
inflammatory processes [71,72]. Evidence suggests that the actions of omega-3 promote an anti-inflammatory state, while the actions of omega- 6 increase inflammation [71, 72]. Increased ingestion of omega6 fatty acid leads to the overproduction of omega- 6 derived signaling molecules (eicosanoids), which when produced in large amounts appear to contribute to the onset of an inflammatory state through a variety of mechanisms, including the release of proinflammatory cytokines [73]. Furthermore, increased omega- 6 in the human diet coincides with the rising prevalence of obesity, a significant risk factor for $\mathrm{AD}$ development and progression that leads to widespread, systemic inflammation [71, 72]. A systematic review of 13 animal studies and 14 human studies supports the association between dietary omega-3/omega- 6 fatty acids and the risk of developing AD [74]. The evidence supports the role of omega-3 as an anti-inflammatory fatty acid in preventing cognitive decline in $\mathrm{AD}$ at the early stage of the disease.

\section{GLUTEN SENSITIVITY}

Celiac disease (CD) is an autoimmune disease triggered by the ingestion of gluten that affects approximately $1 \%$ of the population $[75,76]$. Recently, $\mathrm{CD}$ has come to be understood as only one of a possible range of clinical manifestations of gluten sensitivity diseases $[75,77]$. Non-celiac gluten sensitivity (NCGS) is a syndrome characterized by symptoms related to the ingestion of gluten in the absence of CD or wheat allergy [77].

\section{Non-celiac gluten sensitivity}

NCGS may provoke AD pathology by initiating an overzealous immune system response following gluten ingestion which leads to a chronic state of inflammation [77, 78]. The first studies of NCGS indicated that only the innate immune system was involved in its pathogenesis [78, 79], but recent studies have detected the presence of anti-gliadin antibodies that may indicate the involvement of adaptive immunity [80, 81]. Diagnostic complications and ambiguous symptoms contribute to widespread disease mismanagement of NCGS, which prolongs the activation of the immune system and associated inflammation [81]. If it is accepted that NCGS promotes a chronic inflammatory state in a method analogous to obesity or traumatic brain injury [4], recognized risk factors for $\mathrm{AD}$, then
NCGS may lead to brain neuroinflammation and AD pathogenesis.

\section{Celiac disease}

In CD individuals, genetic susceptibility is present in the form of specific mutations to the major histocompatibility (MHC class II) alleles [82]. MHC class II molecules are present on antigen-presenting cells, where their role is to present antigenic peptides to other immune cells, like the T cells. Mutated forms of the gene can bind gluten peptides and activate $T$ cells in the mucosa of the small intestine $[82,83]$. Once activated, these $\mathrm{T}$ cells increase the production of the cytokine IFN- $\gamma$, which leads to mucosal damage of the small intestine [82, 84, 85].

Individuals with CD display increased small intestine permeability as a consequence of autoimmune pathology [78]. The bacteria and fungi that colonize the digestive tract secrete amyloids, lipopolysaccharides [31], and other microbial exudates from their outer membranes [86-90]. Under conditions of increased intestinal permeability, these microbial amyloids and lipopolysaccharides may escape from the digestive tract and induce the immune system to increase the secretion of pro-inflammatory cytokines $[88,91,92]$. Thus, increased intestinal permeability in CD may contribute to the onset of a chronic peripheral inflammatory state and thus the pathogenesis of AD. For further discussion of this topic, see the following section on the microbiome.

\section{MICROBIOME}

The microbiome influences the activity of the CNS, and the CNS influences the activity of the microbiome [93, 94]. Disturbances that alter the composition of the gut microbiome may stimulate various pathways that ultimately increase the risk of AD. Gut microbiota may be disturbed following exposure to antibiotic treatment, dietary changes, non-steroidal anti-inflammatory medications, food additives, various health conditions, and pathogenic infections [88, 95-99].

\section{Increased gut permeability and bacterial secretions}

Bacteria and fungi that colonize the human digestive tract secrete amyloids, lipopolysaccharides [31], and other microbial exudates from their outer membranes [86-90, 100]. For example, Escherichia coli 
produce extracellular amyloids, curli fibers that facilitate surface adhesion. Microbiome amyloid products such as CsgA, curli, and the $A \beta_{42}$ peptides are recognized by TLR2/TLR1 receptors that are mediated pro-inflammatory responses [90]. Humans appear to sustain life-long exposure to large quantities of amyloid protein secreted by the gut microbiota, which may ultimately contribute to the pathogenesis of $\mathrm{AD}$ during aging [101-103]. Both aging and gut microbiota dysregulation contribute to an increase in the permeability or "leakiness" of the gut [94, 104]; thus, under certain conditions, these microbial amyloids and lipopolysaccharides may escape from the digestive tract and cause the immune system to increase secretion of proinflammatory cytokines [88, 91, 92]. Increased proinflammatory cytokine secretion may contribute to the onset of insulin resistance, a recognized risk factor for $\mathrm{AD}[88,105]$. Additionally, an increase in the overall inflammatory state may itself contribute to the pathogenesis of $\mathrm{AD}$.

Furthermore, the leaked bacterial-derived amyloids could cause an increase in ROS and subsequent activation of $\mathrm{NF}-\kappa \mathrm{B}$, leading to upregulation of microRNA-34a. NF- $\kappa$ B is an essential mediator of inflammatory responses including expression of proinflammatory genes such as cytokines, activation, and differentiation of innate immune cells such as inflammatory $\mathrm{T}$ cells, and activation of inflammatory caspases such as NLRP3 inflammasome [106]. Furthermore, NF- $\kappa \mathrm{B}$ increases the expression of microRNA-34, appearing to downregulate the expression of triggering receptors expressed on myeloid cells 2 (TREM2) [88]. Since TREM2 directly participates in the sensing and clearance of $A \beta_{40}$ and $A \beta_{42}$ peptides, it is probable that its downregulation will lead to impaired peptide phagocytosis and enhanced amyloid aggregation [88, 107, 108].

In addition, alterations in the amounts of the neurotransmitters $\gamma$-aminobutyric acid (GABA), serotonin (5-hydroxytryptamine), brain-derived neurotrophic factor, and glutamate due to changes in microbiome status may contribute to the pathogenesis of $\mathrm{AD}$ [94, 109].

\section{The hygiene hypothesis}

The hygiene hypothesis posits that an overly hygienic Western lifestyle that includes the use of food additives, the abuse of antibiotics, clean drinking water, and a generally high level of sanitation, results in lower levels of infection and ultimately immune system dysfunction [94]. A new interpretation of the hygiene hypothesis, the microflora hypothesis, suggests that high sanitation alters the colonization of the infant gut, which disrupts the development of the immune system and leads to diseases [110]. While the mechanism of microbial modulation of host immunity is incompletely understood, some evidence suggests the role of $\mathrm{T}$ cells, specifically regulatory $\mathrm{T}$ cells, regarding immune response [94, 111-114]. Regulatory T cells act to suppress possibly harmful activities of the helper $\mathrm{T}$ cells, regulate the strength of the immune response [115-117], and protect commensal bacteria from elimination by the immune system [116, 118]. Inadequate exposure to microorganisms may fail to induce the differentiation of naïve $\mathrm{T}$ cells to regulatory $\mathrm{T}$ cells, rather than helper $\mathrm{T}$ cells [114]. Dysfunction of regulatory $\mathrm{T}$ cells has been suggested to partially modulate the relationship between decreased microbial exposure and the increased prevalence of allergic disease, autoimmune disease, and chronic inflammatory diseases in the rich, developed countries [94, 111, 112]. Considering the parallels that can be drawn between $\mathrm{AD}$ and both the chronic inflammatory diseases and the autoimmune diseases, it is possible that the hygiene/microflora hypothesis may be applied as a framework to understand the rapid increase of $\mathrm{AD}$ pathology in recent years.

\section{DISCUSSION}

Genetics and unhealthy lifestyle habits, such as a noxious diet, can increase susceptibility to chronic inflammatory diseases $[119,120]$. A Western diet induces systemic inflammation and alters innate immunity by reprogramming of myeloid progenitor cells to enhance immune responses [121]. However, one study suggests that the Mediterranean diet reduces the risk of $\mathrm{AD}$ and cognitive decline in individuals [122]. Scarmeas [123] also suggested that the Mediterranean diet reduces the risk of conversion from mild cognitive impairment to $\mathrm{AD}$ [124]. The beneficial components of the Mediterranean diet such as higher intake of fish, fruits, and vegetables rich in omega-3, olive oils, vitamins, phenols, and polyphenols provide antioxidant and anti-inflammatory properties, which are both important in the pathogenesis of AD [125-129]. The clinical trial, Three-City Study, also indicates that the Mediterranean diet is associated with a slower cognitive decline on the Mini-Mental State Examination. However, its association with the risk of 
dementia is not indicated [123]. Freat indicates that the major difference between the Three-City Study and Scarmeas's study is the use of multi-vitamins and supplements, and also the length of follow-up regarding the risk of dementia. Furthermore, identification of the disease at the earlier stage of $\mathrm{AD}$, by using new imaging technology, might provide a window of opportunity to use the protective effects of the Mediterranean diet against cognitive decline. By the time of clinical diagnosis of dementia and $\mathrm{AD}$, it is likely too late to reverse the physiopathology of the disease.

The Mediterranean diet is a low carb diet with lean amounts of protein. Kroemer and colleagues characterize the excessive intake of carbohydrates that mediated noxious effects on human health as "carbotoxicity". Low carb diets with adequate protein consumption cause ketogenesis, which is the conversion of body fat into ketones. Ketogenesis confers neuroprotective properties to the body through reduction of inflammation and oxidative stress, and increase in autophagy [130].

There is little known about the connection between gluten sensitivity and cognitive decline. However, nutrient deficiency, inflammation, and strong immune response in the brain puts patients with $\mathrm{CD}$ at higher risk of cognitive decline.

As the literature indicates, inflammation contributes to $\mathrm{AD}$ pathogenesis. Inflammatory pathways can accelerate the progression of $\mathrm{AD}$ [131] and several other age-related diseases [132]. An antiinflammatory therapy should be beneficial in delaying the progression of AD. However, the results are far from conclusive [131]. It is important to know chronic inflammation is linked to the neurobiology and progression of $\mathrm{AD}$ [133] through different mechanisms, such as production and clearance of $A \beta$. $A \beta$ plaques can trigger inflammation in a positive feedback loop [132].

\section{CONCLUSION}

Diet plays a significant role in introducing antioxidant and anti-inflammatory factors, shaping microbiomes, and treating digestive problems such as gluten sensitivity, that might decelerate inflammation and AD progression (Fig. 1). The inflammatory events throughout an individual's lifetime suggest the presence of a chronic inflammatory condition. The cumulative effects of this chronic inflammation may impact the different stages of AD [132]. Developing

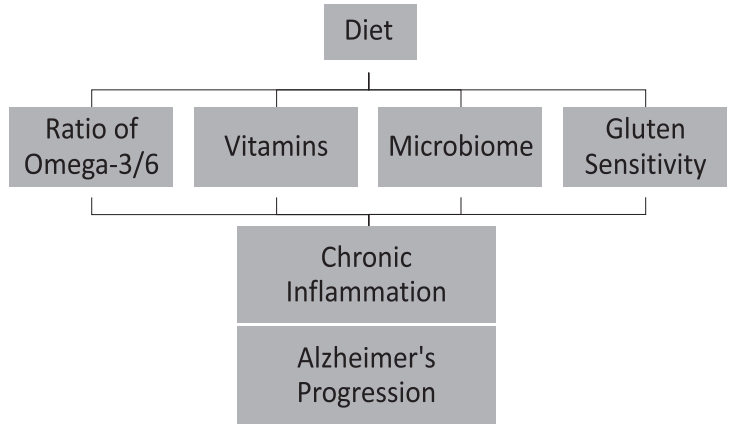

Fig. 1. Diet can accelerate Alzheimer's disease progression throughout chronic inflammation.

anti-inflammatory approaches to lifestyle habits may likely slow the progression, or delay the onset of AD. Health behavior interventions, such as dietary intake, may delay or slow the progression of AD [134-136] by 3 to 5 years [3]. Educating the public on delaying $\mathrm{AD}$ by early detection of the disease in combination with early intervention can act as effective methods to attenuate AD. Furthermore, interventional studies are necessary for considering whether a low antioxidant and anti-inflammatory diet contributes to the progression of $\mathrm{AD}$ and whether a high antioxidant and anti-inflammatory diet can reduce the risk of cognitive impairment and AD.

\section{ACKNOWLEDGMENTS}

We would like to thank Dr. Stinson, Lamar School of Nursing Chair, and Dr. David Cocke, Gill Professor at Lamar University, for their support on this project.

\section{CONFLICT OF INTEREST}

The authors have no conflict of interest to report.

\section{REFERENCES}

[1] Langa KM (2018) Future Directions for the Demography of Aging: Proceedings of a Workshop. National Academies Press (US), Washington DC.

[2] Matyas N, Auer S, Gisinger C, Kil M, Keser Aschenberger F, Klerings I, Gartlehner G (2017) Continuing education for the prevention of mild cognitive impairment and Alzheimer's-type dementia: A systematic review protocol. Syst Rev 6, 157.

[3] Zissimopoulos J, Crimmins E, St Clair P (2014) The value of delaying Alzheimer's disease onset. Forum Health Econ Policy 18, 25-39. 
[4] Heneka MT, Carson MJ, El Khoury J, Landreth GE, Brosseron F, Feinstein DL, Jacobs AH, Wyss-Coray T, Vitorica J, Ransohoff RM, Herrup K, Frautschy SA, Finsen B, Brown GC, Verkhratsky A, Yamanaka K, Koistinaho J, Latz E, Halle A, Petzold GC, Town T, Morgan D, Shinohara ML, Perry VH, Holmes C, Bazan NG, Brooks DJ, Hunot S, Joseph B, Deigendesch N, Garaschuk O, Boddeke E, Dinarello CA, Breitner JC, Cole GM, Golenbock DT, Kummer MP (2015) Neuroinflammation in Alzheimer's disease. Lancet Neurol 14, 388-405.

[5] Heppner FL, Ransohoff RM, Becher B (2015) Immune attack: The role of inflammation in Alzheimer disease. Nat Rev Neurosci 16, 358-372.

[6] Van Eldik LJ, Carrillo MC, Cole PE, Feuerbach D, Greenberg BD, Hendrix JA, Kennedy M, Kozauer N, Margolin RA, Molinuevo JL, Mueller R, Ransohoff RM, Wilcock DM, Bain L, Bales K (2016) The roles of inflammation and immune mechanisms in Alzheimer's disease. Alzheimers Dement (N Y) 2, 99-109.

[7] Takeda S, Sato N, Morishita R (2014) Systemic inflammation, blood-brain barrier vulnerability and cognitive/non-cognitive symptoms in Alzheimer disease: Relevance to pathogenesis and therapy. Front Aging Neurosci $\mathbf{6}, 171$.

[8] Fischer VW, Siddiqi A, Yusufaly Y (1990) Altered angioarchitecture in selected areas of brains with Alzheimer's disease. Acta Neuropathol 79, 672-679.

[9] Shin HK, Jones PB, Garcia-Alloza M, Borrelli L, Greenberg SM, Bacskai BJ, Frosch MP, Hyman BT, Moskowitz MA, Ayata C (2007) Age-dependent cerebrovascular dysfunction in a transgenic mouse model of cerebral amyloid angiopathy. Brain 130, 2310-2319.

[10] Iadecola C (2004) Neurovascular regulation in the normal brain and in Alzheimer's disease. Nat Rev Neurosci 5, 347360.

[11] Greenberg SM, Gurol ME, Rosand J, Smith EE (2004) Amyloid angiopathy-related vascular cognitive impairment. Stroke 35, 2616-2619.

[12] Kinnecom C, Lev MH, Wendell L, Smith EE, Rosand J, Frosch MP, Greenberg SM (2007) Course of cerebral amyloid angiopathy-related inflammation. Neurology $\mathbf{6 8 ,}$ 1411-1416.

[13] Diaz Brinton R, Yamazaki RS (1998) Advances and challenges in the prevention and treatment of Alzheimer's disease. Pharm Res 15, 386-398.

[14] Lampa J, Westman M, Kadetoff D, Agreus AN, Le Maitre E, Gillis-Haegerstrand C, Andersson M, Khademi M, Corr M, Christianson CA, Delaney A, Yaksh TL, Kosek E, Svensson CI (2012) Peripheral inflammatory disease associated with centrally activated IL-1 system in humans and mice. Proc Natl Acad Sci U S A 109, 12728-12733.

[15] Walters A, Phillips E, Zheng R, Biju M, Kuruvilla T (2016) Evidence for neuroinflammation in Alzheimer's disease. Prog Neurol Psychiatry 20, 25-31.

[16] Whitmer RA, Gustafson DR, Barrett-Connor E, Haan MN, Gunderson EP, Yaffe K (2008) Central obesity and increased risk of dementia more than three decades later. Neurology 71, 1057-1064.

[17] Sears B, Ricordi C (2011) Anti-inflammatory nutrition as a pharmacological approach to treat obesity. J Obes 2011, 431985.

[18] Sears B (2015) Anti-inflammatory diets. J Am Coll Nutr 34 Suppl 1, 14-21.

[19] Brown BM, Peiffer JJ, Martins RN (2013) Multiple effects of physical activity on molecular and cognitive signs of brain aging: Can exercise slow neurodegeneration and delay Alzheimer's disease? Mol Psychiatry 18, 864-874.

[20] Kennedy DO (2016) B vitamins and the brain: Mechanisms, dose and efficacy-a review. Nutrients $\mathbf{8}, 68$.

[21] Grober U, Kisters K, Schmidt J (2013) Neuroenhancement with vitamin B12-underestimated neurological significance. Nutrients 5, 5031-5045.

[22] Morris MS (2003) Homocysteine and Alzheimer's disease. Lancet Neurol 2, 425-428.

[23] Sun Y, Lu CJ, Chien KL, Chen ST, Chen RC (2007) Efficacy of multivitamin supplementation containing vitamins B6 and B12 and folic acid as adjunctive treatment with a cholinesterase inhibitor in Alzheimer's disease: A 26-week, randomized, double-blind, placebo-controlled study in Taiwanese patients. Clin Ther 29, 2204-2214.

[24] Douaud G, Refsum H, de Jager CA, Jacoby R, Nichols TE, Smith SM, Smith AD (2013) Preventing Alzheimer's disease-related gray matter atrophy by B-vitamin treatment. Proc Natl Acad Sci U S A 110, 9523-9528.

[25] Zhang DM, Ye JX, Mu JS, Cui XP (2017) Efficacy of vitamin B supplementation on cognition in elderly patients with cognitive-related diseases. J Geriatr Psychiatry Neurol 30, 50-59.

[26] Monacelli F, Acquarone E, Giannotti C, Borghi R, Nencioni A (2017) Vitamin C, aging and Alzheimer's disease. Nutrients 9, E670.

[27] Rinaldi P, Polidori MC, Metastasio A, Mariani E, Mattioli P, Cherubini A, Catani M, Cecchetti R, Senin U, Mecocci P (2003) Plasma antioxidants are similarly depleted in mild cognitive impairment and in Alzheimer's disease. Neurobiol Aging 24, 915-919.

[28] Charlton KE, Rabinowitz TL, Geffen LN, Dhansay MA (2004) Lowered plasma vitamin C, but not vitamin E, concentrations in dementia patients. J Nutr Health Aging $\mathbf{8}$, 99-107.

[29] von Arnim CA, Herbolsheimer F, Nikolaus T, Peter R, Biesalski HK, Ludolph AC, Riepe M, Nagel G, ActiFE Ulm Study Group (2012) Dietary antioxidants and dementia in a population-based case-control study among older people in South Germany. J Alzheimers Dis 31, 717-724.

[30] Riscuta G (2016) Nutrigenomics at the interface of aging, lifespan, and cancer prevention. J Nutr 146, 1931-1939.

[31] Jack CR Jr, Albert MS, Knopman DS, McKhann GM, Sperling RA, Carrillo MC, Thies B, Phelps CH (2011) Introduction to the recommendations from the National Institute on Aging-Alzheimer's Association workgroups on diagnostic guidelines for Alzheimer's disease. Alzheimers Dement 7, 257-262.

[32] Huang YN, Lai CC, Chiu CT, Lin JJ, Wang JY (2014) L-ascorbate attenuates the endotoxin-induced production of inflammatory mediators by inhibiting MAPK activation and NF-kappaB translocation in cortical neurons/glia cocultures. PLoS One 9, e97276.

[33] Dixit S, Bernardo A, Walker JM, Kennard JA, Kim GY, Kessler ES, Harrison FE (2015) Vitamin C deficiency in the brain impairs cognition, increases amyloid accumulation and deposition, and oxidative stress in APP/PSEN1 and normally aging mice. ACS Chem Neurosci 6, 570-581.

[34] Kook SY, Lee KM, Kim Y, Cha MY, Kang S, Baik SH, Lee H, Park R, Mook-Jung I (2014) High-dose of vitamin $\mathrm{C}$ supplementation reduces amyloid plaque burden and ameliorates pathological changes in the brain of 5XFAD mice. Cell Death Dis 5, e1083.

[35] Murakami K, Murata N, Ozawa Y, Kinoshita N, Irie K, Shirasawa T, Shimizu T (2011) Vitamin C restores behavioral 
deficits and amyloid-beta oligomerization without affecting plaque formation in a mouse model of Alzheimer's disease. J Alzheimers Dis 26, 7-18.

[36] Cheng F, Cappai R, Ciccotosto GD, Svensson G, Multhaup G, Fransson LA, Mani K (2011) Suppression of amyloid beta A11 antibody immunoreactivity by vitamin C: Possible role of heparan sulfate oligosaccharides derived from glypican-1 by ascorbate-induced, nitric oxide (NO)catalyzed degradation. J Biol Chem 286, 27559-27572.

[37] Zandi PP, Anthony JC, Khachaturian AS, Stone SV, Gustafson D, Tschanz JT, Norton MC, Welsh-Bohmer KA, Breitner JC, Cache County Study Group (2004) Reduced risk of Alzheimer disease in users of antioxidant vitamin supplements: The Cache County Study. Arch Neurol 61, 82-88.

[38] Nualart F, Mack L, Garcia A, Cisternas P, Bongarzone ER, Heitzer M, Jara N, Martinez F, Ferrada L, Espinoza F, Baeza V, Salazar K (2014) Vitamin C transporters, recycling and the bystander effect in the nervous system: SVCT2 versus Gluts. J Stem Cell Res Ther 4, 209.

[39] Vasefi MS, Yang K, Li J, Kruk JS, Heikkila JJ, Jackson MF, MacDonald JF, Beazely MA (2013) Acute 5-HT7 receptor activation increases NMDA-evoked currents and differentially alters NMDA receptor subunit phosphorylation and trafficking in hippocampal neurons. Mol Brain 6, 24.

[40] Abd-Elrahman KS, Hamilton A, Vasefi M, Ferguson SSG (2018) Autophagy is increased following either pharmacological or genetic silencing of mGluR5 signaling in Alzheimer's disease mouse models. Mol Brain 11, 19.

[41] Kocot J, Luchowska-Kocot D, Kielczykowska M, Musik I, Kurzepa J (2017) Does vitamin C influence neurodegenerative diseases and psychiatric disorders? Nutrients 9, E659.

[42] Pogge E (2010) Vitamin D and Alzheimer's disease: Is there a link? Consult Pharm 25, 440-450.

[43] Balion C, Griffith LE, Strifler L, Henderson M, Patterson C, Heckman G, Llewellyn DJ, Raina P (2012) Vitamin D, cognition, and dementia: A systematic review and metaanalysis. Neurology 79, 1397-1405.

[44] Yesil Y, Kuyumcu ME, Kara O, Halacli B, Etgul S, Kizilarslanoglu MC, Yavuz BB, Ozcan M, Halil MG, Sahin Cankurtaran E, Cankurtaran M, Ariogul S (2015) Vitamin D status and its association with gradual decline in cognitive function. Turk J Med Sci 45, 1051-1057.

[45] Landel V, Annweiler C, Millet P, Morello M, Feron F (2016) Vitamin D, cognition and Alzheimer's disease: The therapeutic benefit is in the D-Tails. J Alzheimers Dis 53, 419-444.

[46] Anjum I, Jaffery SS, Fayyaz M, Samoo Z, Anjum S (2018) The role of vitamin D in brain health: A mini literature review. Cureus 10, e2960.

[47] Rege SD, Geetha T, Broderick TL, Babu JR (2017) Can diet and physical activity limit Alzheimer's disease risk? Curr Alzheimer Res 14, 76-93.

[48] Etgen T, Chonchol M, Forstl H, Sander D (2012) Chronic kidney disease and cognitive impairment: A systematic review and meta-analysis. Am J Nephrol 35, 474-482.

[49] Bhatti AB, Usman M, Ali F, Satti SA (2016) Vitamin supplementation as an adjuvant treatment for Alzheimer's disease. J Clin Diagn Res 10, OE07-11.

[50] Xiao Q, Gil SC, Yan P, Wang Y, Han S, Gonzales E, Perez R, Cirrito JR, Lee JM (2012) Role of phosphatidylinositol clathrin assembly lymphoid-myeloid leukemia (PICALM) in intracellular amyloid precursor protein (APP) process- ing and amyloid plaque pathogenesis. J Biol Chem 287, 21279-21289.

[51] Berridge MJ (2016) The inositol trisphosphate/calcium signaling pathway in health and disease. Physiol Rev 96, 1261-1296.

[52] Miller BJ, Whisner CM, Johnston CS (2016) Vitamin D supplementation appears to increase plasma Abeta40 in vitamin D insufficient older adults: A pilot randomized controlled trial. J Alzheimers Dis 52, 843-847.

[53] Annweiler C, Schott AM, Rolland Y, Blain H, Herrmann FR, Beauchet O (2010) Dietary intake of vitamin D and cognition in older women: A large population-based study. Neurology 75, 1810-1816.

[54] Annweiler C, Herrmann FR, Fantino B, Brugg B, Beauchet $\mathrm{O}$ (2012) Effectiveness of the combination of memantine plus vitamin $\mathrm{D}$ on cognition in patients with Alzheimer disease: A pre-post pilot study. Cogn Behav Neurol 25, 121-127.

[55] Dong Y, Chen X, Liu Y, Shu Y, Chen T, Xu L, Li M, Guan X (2018) Do low-serum vitamin E levels increase the risk of Alzheimer disease in older people? Evidence from a meta-analysis of case-control studies. Int J Geriatr Psychiatry 33, e257-e263.

[56] Grimm MO, Mett J, Hartmann T (2016) The impact of vitamin $\mathrm{E}$ and other fat-soluble vitamins on Alzheimer's disease. Int J Mol Sci 17, E1785.

[57] Rota C, Rimbach G, Minihane AM, Stoecklin E, Barella L (2005) Dietary vitamin E modulates differential gene expression in the rat hippocampus: Potential implications for its neuroprotective properties. Nutr Neurosci 8, 21-29.

[58] Santos MS, Meydani M(1997) Vitamin E supplementation and plasma ascorbate. Am J Clin Nutr 66, 708-710.

[59] Petersen RC, Thomas RG, Grundman M, Bennett D, Doody R, Ferris S, Galasko D, Jin S, Kaye J, Levey A, Pfeiffer E, Sano M, van Dyck CH, Thal LJ, Alzheimer's Disease Cooperative Study Group (2005) Vitamin E and donepezil for the treatment of mild cognitive impairment. N Engl J Med 352, 2379-2388.

[60] Lloret A, Badia MC, Mora NJ, Pallardo FV, Alonso MD, Vina J (2009) Vitamin E paradox in Alzheimer's disease: It does not prevent loss of cognition and may even be detrimental. J Alzheimers Dis 17, 143-149.

[61] Dysken MW, Sano M, Asthana S, Vertrees JE, Pallaki M, Llorente M, Love S, Schellenberg GD, McCarten JR, Malphurs J, Prieto S, Chen P, Loreck DJ, Trapp G, Bakshi RS, Mintzer JE, Heidebrink JL, Vidal-Cardona A, Arroyo LM, Cruz AR, Zachariah S, Kowall NW, Chopra MP, Craft S, Thielke S, Turvey CL, Woodman C, Monnell KA, Gordon K, Tomaska J, Segal Y, Peduzzi PN, Guarino PD (2014) Effect of vitamin $\mathrm{E}$ and memantine on functional decline in Alzheimer disease: The TEAM-AD VA cooperative randomized trial. JAMA 311, 33-44.

[62] Kryscio RJ, Abner EL, Caban-Holt A, Lovell M, Goodman P, Darke AK, Yee M, Crowley J, Schmitt FA (2017) Association of antioxidant supplement use and dementia in the Prevention of Alzheimer's Disease by Vitamin E and Selenium Trial (PREADViSE). JAMA Neurol 74, 567-573.

[63] Presse N, Shatenstein B, Kergoat MJ, Ferland G (2008) Low vitamin $\mathrm{K}$ intakes in community-dwelling elders at an early stage of Alzheimer's disease. J Am Diet Assoc 108, 2095-2099.

[64] Sato Y, Honda Y, Hayashida N, Iwamoto J, Kanoko T, Satoh K (2005) Vitamin K deficiency and osteopenia in elderly women with Alzheimer's disease. Arch Phys Med Rehabil 86, 576-581. 
[65] Shatenstein B, Kergoat MJ, Reid I (2007) Poor nutrient intakes during 1-year follow-up with community-dwelling older adults with early-stage Alzheimer dementia compared to cognitively intact matched controls. $J$ Am Diet Assoc 107, 2091-2099.

[66] Annweiler C, Ferland G, Barberger-Gateau P, Brangier A, Rolland Y, Beauchet O (2015) Vitamin K antagonists and cognitive impairment: Results from a cross-sectional pilot study among geriatric patients. J Gerontol A Biol Sci Med Sci 70, 97-101.

[67] Alisi L, Cao R, De Angelis C, Cafolla A, Caramia F, Cartocci G, Librando A, Fiorelli M (2019) The relationships between vitamin $\mathrm{K}$ and cognition: A review of current evidence. Front Neurol 10, 239.

[68] van Echten-Deckert G, Walter J (2012) Sphingolipids: Critical players in Alzheimer's disease. Prog Lipid Res 51, 378-393.

[69] Galasko DR, Peskind E, Clark CM, Quinn JF, Ringman JM, Jicha GA, Cotman C, Cottrell B, Montine TJ, Thomas RG, Aisen P, Alzheimer's Disease Cooperative Study (2012) Antioxidants for Alzheimer disease: A randomized clinical trial with cerebrospinal fluid biomarker measures. Arch Neurol 69, 836-841.

[70] Cornelli U (2010) Treatment of Alzheimer's disease with a cholinesterase inhibitor combined with antioxidants. Neurodegener Dis 7, 193-202.

[71] Simopoulos AP (2001) Evolutionary aspects of diet and essential fatty acids. World Rev Nutr Diet 88, 18-27.

[72] Simopoulos AP (2016) An increase in the omega6/omega-3 fatty acid ratio increases the risk for obesity. Nutrients 8, 128.

[73] DiNicolantonio JJ, O'Keefe JH (2018) Importance of maintaining a low omega-6/omega-3 ratio for reducing inflammation. Open Heart 5, e000946.

[74] Loef M, Walach H (2013) The omega-6/omega-3 ratio and dementia or cognitive decline: A systematic review on human studies and biological evidence. J Nutr Gerontol Geriatr 32, 1-23.

[75] Hadjivassiliou M, Sanders DS, Grunewald RA, Woodroofe N, Boscolo S, Aeschlimann D (2010) Gluten sensitivity: From gut to brain. Lancet Neurol 9, 318-330.

[76] Jackson JR, Eaton WW, Cascella NG, Fasano A, Kelly DL (2012) Neurologic and psychiatric manifestations of celiac disease and gluten sensitivity. Psychiatr $Q \mathbf{8 3}$, 91-102.

[77] Losurdo G, Principi M, Iannone A, Amoruso A, Ierardi E, Di Leo A, Barone M (2018) Extra-intestinal manifestations of non-celiac gluten sensitivity: An expanding paradigm. World J Gastroenterol 24, 1521-1530.

[78] Sapone A, Lammers KM, Casolaro V, Cammarota M, Giuliano MT, De Rosa M, Stefanile R, Mazzarella G, Tolone C, Russo MI, Esposito P, Ferraraccio F, Carteni M, Riegler G, de Magistris L, Fasano A (2011) Divergence of gut permeability and mucosal immune gene expression in two gluten-associated conditions: Celiac disease and gluten sensitivity. BMC Med 9, 23.

[79] Sapone A, Lammers KM, Mazzarella G, Mikhailenko I, Carteni M, Casolaro V, Fasano A (2010) Differential mucosal IL-17 expression in two gliadin-induced disorders: Gluten sensitivity and the autoimmune enteropathy celiac disease. Int Arch Allergy Immunol 152, 75-80.

[80] Brottveit M, Beitnes AC, Tollefsen S, Bratlie JE, Jahnsen FL, Johansen FE, Sollid LM, Lundin KE (2013) Mucosal cytokine response after short-term gluten challenge in celiac disease and non-celiac gluten sensitivity. Am J Gastroenterol 108, 842-850.

[81] Caio G, Riegler G, Patturelli M, Facchiano A, L DEM, Sapone A (2017) Pathophysiology of non-celiac gluten sensitivity: Where are we now? Minerva Gastroenterol Dietol 63, 16-21.

[82] Kagnoff MF (2007) Celiac disease: Pathogenesis of a model immunogenetic disease. J Clin Invest 117, 41-49.

[83] Molberg O, Kett K, Scott H, Thorsby E, Sollid LM, Lundin KE (1997) Gliadin specific, HLA DQ2-restricted T cells are commonly found in small intestinal biopsies from coeliac disease patients, but not from controls. Scand $J$ Immunol 46, 103-108.

[84] Nilsen EM, Jahnsen FL, Lundin KE, Johansen FE, Fausa O, Sollid LM, Jahnsen J, Scott H, Brandtzaeg P (1998) Gluten induces an intestinal cytokine response strongly dominated by interferon gamma in patients with celiac disease. Gastroenterology 115, 551-563.

[85] Przemioslo RT, Lundin KE, Sollid LM, Nelufer J, Ciclitira PJ (1995) Histological changes in small bowel mucosa induced by gliadin sensitive $\mathrm{T}$ lymphocytes can be blocked by anti-interferon gamma antibody. Gut $\mathbf{3 6}$, 874-879.

[86] Bhattacharjee S, Lukiw WJ (2013) Alzheimer's disease and the microbiome. Front Cell Neurosci 7, 153.

[87] Hufnagel DA, Tukel C, Chapman MR (2013) Disease to dirt: The biology of microbial amyloids. PLoS Pathog 9 , e1003740.

[88] Pistollato F, Sumalla Cano S, Elio I, Masias Vergara M, Giampieri F, Battino M (2016) Role of gut microbiota and nutrients in amyloid formation and pathogenesis of Alzheimer disease. Nutr Rev 74, 624-634.

[89] Syed AK, Boles BR (2014) Fold modulating function: Bacterial toxins to functional amyloids. Front Microbiol $\mathbf{5}, 401$.

[90] Zhao Y, Dua P, Lukiw WJ (2015) Microbial sources of amyloid and relevance to amyloidogenesis and Alzheimer's disease (AD). J Alzheimers Dis Parkinsonism $5,177$.

[91] Daulatzai MA (2014) Chronic functional bowel syndrome enhances gut-brain axis dysfunction, neuroinflammation, cognitive impairment, and vulnerability to dementia. $\mathrm{Neu}$ rochem Res 39, 624-644.

[92] Daulatzai MA (2014) Role of stress, depression, and aging in cognitive decline and Alzheimer's disease. Curr Top Behav Neurosci 18, 265-296.

[93] Cryan JF, O'Mahony SM (2011) The microbiome-gutbrain axis: From bowel to behavior. Neurogastroenterol Motil 23, 187-192.

[94] Hu X, Wang T, Jin F (2016) Alzheimer's disease and gut microbiota. Sci China Life Sci 59, 1006-1023.

[95] Bjorklund M, Ouwehand AC, Forssten SD, Nikkila J, Tiihonen K, Rautonen N, Lahtinen SJ (2012) Gut microbiota of healthy elderly NSAID users is selectively modified with the administration of Lactobacillus acidophilus NCFM and lactitol. Age (Dordr) 34, 987-999.

[96] Delzenne NM, Neyrinck AM, Cani PD (2011) Modulation of the gut microbiota by nutrients with prebiotic properties: Consequences for host health in the context of obesity and metabolic syndrome. Microb Cell Fact 10(Suppl 1), S10.

[97] Muegge BD, Kuczynski J, Knights D, Clemente JC, Gonzalez A, Fontana L, Henrissat B, Knight R, Gordon JI (2011) Diet drives convergence in gut microbiome func- 
tions across mammalian phylogeny and within humans. Science 332, 970-974.

[98] Scott KP, Gratz SW, Sheridan PO, Flint HJ, Duncan SH (2013) The influence of diet on the gut microbiota. Pharmacol Res 69, 52-60.

[99] Suez J, Korem T, Zeevi D, Zilberman-Schapira G, Thaiss CA, Maza O, Israeli D, Zmora N, Gilad S, Weinberger A, Kuperman Y, Harmelin A, Kolodkin-Gal I, Shapiro H, Halpern Z, Segal E, Elinav E (2014) Artificial sweeteners induce glucose intolerance by altering the gut microbiota. Nature 514, 181-186.

[100] Hill JM, Lukiw WJ (2015) Microbial-generated amyloids and Alzheimer's disease (AD). Front Aging Neurosci 7, 9.

[101] Marques F, Sousa JC, Sousa N, Palha JA (2013) Bloodbrain-barriers in aging and in Alzheimer's disease. $\mathrm{Mol}$ Neurodegener $\mathbf{8}, 38$.

[102] Shoemark DK, Allen SJ (2015) The microbiome and disease: Reviewing the links between the oral microbiome, aging, and Alzheimer's disease. J Alzheimers Dis 43, 725738.

[103] Tran L, Greenwood-Van Meerveld B (2013) Ageassociated remodeling of the intestinal epithelial barrier. J Gerontol A Biol Sci Med Sci 68, 1045-1056.

[104] Jakobsson HE, Rodriguez-Pineiro AM, Schutte A, Ermund A, Boysen P, Bemark M, Sommer F, Backhed F, Hansson GC, Johansson ME (2015) The composition of the gut microbiota shapes the colon mucus barrier. EMBO Rep 16, 164-177.

[105] Bekkering P, Jafri I, van Overveld FJ, Rijkers GT (2013) The intricate association between gut microbiota and development of type 1, type 2 and type 3 diabetes. Expert Rev Clin Immunol 9, 1031-1041.

[106] Liu T, Zhang L, Joo D, Sun SC (2017) NF-kappaB signaling in inflammation. Signal Transduct Target Ther 2, 17023 .

[107] Zhao Y, Lukiw WJ (2013) TREM2 signaling, miRNA-34a and the extinction of phagocytosis. Front Cell Neurosci 7, 131.

[108] Zhao Z, Sagare AP, Ma Q, Halliday MR, Kong P, Kisler K, Winkler EA, Ramanathan A, Kanekiyo T, Bu G, Owens NC, Rege SV, Si G, Ahuja A, Zhu D, Miller CA, Schneider JA, Maeda M, Maeda T, Sugawara T, Ichida JK, Zlokovic BV (2015) Central role for PICALM in amyloidbeta blood-brain barrier transcytosis and clearance. Nat Neurosci 18, 978-987.

[109] Maqsood R, Stone TW (2016) The gut-brain axis, BDNF, NMDA and CNS disorders. Neurochem Res 41, 28192835.

[110] Azad MB, Konya T, Maughan H, Guttman DS, Field CJ, Sears MR, Becker AB, Scott JA, Kozyrskyj AL (2013) Infant gut microbiota and the hygiene hypothesis of allergic disease: Impact of household pets and siblings on microbiota composition and diversity. Allergy Asthma Clin Immunol 9, 15.

[111] Romagnani S (2004) The increased prevalence of allergy and the hygiene hypothesis: Missing immune deviation, reduced immune suppression, or both? Immunology 112, 352-363.

[112] Rook GA (2007) The hygiene hypothesis and the increasing prevalence of chronic inflammatory disorders. Trans R Soc Trop Med Hyg 101, 1072-1074.

[113] Ryan-Flood R, Rooke A (2009) Que(e)rying methodology: Lessons and dilemmas from lesbian lives: An introduction. J Lesbian Stud 13, 115-121.
[114] Rook GA, Lowry CA (2008) The hygiene hypothesis and psychiatric disorders. Trends Immunol 29, 150-158.

[115] Cohn M (2008) What roles do regulatory T cells play in the control of the adaptive immune response? Int Immunol 20, $1107-1118$.

[116] Corthay A (2009) How do regulatory T cells work? Scand J Immunol 70, 326-336.

[117] Oldenhove G, de Heusch M, Urbain-Vansanten G, Urbain J, Maliszewski C, Leo O, Moser M (2003) $\mathrm{CD} 4+\mathrm{CD} 25+$ regulatory $\mathrm{T}$ cells control T helper cell type 1 responses to foreign antigens induced by mature dendritic cells in vivo. $J$ Exp Med 198, 259-266.

[118] Dembic Z (2008) Beginning of the end of (understanding) the immune response. Scand J Immunol 68, 381-382.

[119] Mega JL, Stitziel NO, Smith JG, Chasman DI, Caulfield M, Devlin JJ, Nordio F, Hyde C, Cannon CP, Sacks F, Poulter N, Sever P, Ridker PM, Braunwald E, Melander O, Kathiresan S, Sabatine MS (2015) Genetic risk, coronary heart disease events, and the clinical benefit of statin therapy: An analysis of primary and secondary prevention trials. Lancet 385, 2264-2271.

[120] Khera AV, Emdin CA, Drake I, Natarajan P, Bick AG, Cook NR, Chasman DI, Baber U, Mehran R, Rader DJ, Fuster V, Boerwinkle E, Melander O, Orho-Melander M, Ridker PM, Kathiresan S (2016) Genetic risk, adherence to a healthy lifestyle, and coronary disease. $N$ Engl J Med 375, 2349-2358.

[121] Christ A, Gunther P, Lauterbach MAR, Duewell P, Biswas D, Pelka K, Scholz CJ, Oosting M, Haendler K, Bassler K, Klee K, Schulte-Schrepping J, Ulas T, Moorlag S, Kumar V, Park MH, Joosten LAB, Groh LA, Riksen NP, Espevik T, Schlitzer A, Li Y, Fitzgerald ML, Netea MG, Schultze JL, Latz E (2018) Western diet triggers NLRP3dependent innate immune reprogramming. Cell 172, $162-175$ e114.

[122] Scarmeas N, Stern Y, Mayeux R, Luchsinger JA (2006) Mediterranean diet, Alzheimer disease, and vascular mediation. Arch Neurol 63, 1709-1717.

[123] Feart C, Samieri C, Rondeau V, Amieva H, Portet F, Dartigues JF, Scarmeas N, Barberger-Gateau P (2009) Adherence to a Mediterranean diet, cognitive decline, and risk of dementia. JAMA 302, 638-648.

[124] Lakhan SE, Caro M, Hadzimichalis N (2013) NMDA receptor activity in neuropsychiatric disorders. Front Psychiatry 4, 52.

[125] Cummings JL (2004) Alzheimer's disease. N Engl J Med 351, 56-67.

[126] Chrysohoou C, Panagiotakos DB, Pitsavos C, Das UN, Stefanadis C (2004) Adherence to the Mediterranean diet attenuates inflammation and coagulation process in healthy adults: The ATTICA Study. J Am Coll Cardiol 44, 152-158.

[127] Scarmeas N, Stern Y, Mayeux R, Manly JJ, Schupf N, Luchsinger JA (2009) Mediterranean diet and mild cognitive impairment. Arch Neurol 66, 216-225.

[128] Mancini M, Parfitt VJ, Rubba P (1995) Antioxidants in the Mediterranean diet. Can J Cardiol 11(Suppl G), 105G109G.

[129] Sanchez-Moreno C, Cano MP, de Ancos B, Plaza L, Olmedilla B, Granado F, Martin A (2006) Mediterranean vegetable soup consumption increases plasma vitamin $\mathrm{C}$ and decreases F2-isoprostanes, prostaglandin E2 and monocyte chemotactic protein-1 in healthy humans. J Nutr Biochem 17, 183-189. 
[130] Kroemer G, Lopez-Otin C, Madeo F, de Cabo R (2018) Carbotoxicity-noxious effects of carbohydrates. Cell 175, 605-614.

[131] Eikelenboom P, Hoozemans JJ, Veerhuis R, van Exel E, Rozemuller AJ, van Gool WA (2012) Whether, when and how chronic inflammation increases the risk of developing late-onset Alzheimer's disease. Alzheimers Res Ther 4,15 .

[132] Newcombe EA, Camats-Perna J, Silva ML, Valmas N, Huat TJ, Medeiros R (2018) Inflammation: The link between comorbidities, genetics, and Alzheimer's disease. J Neuroinflammation 15, 276.

[133] Hauss-Wegrzyniak B, Dobrzanski P, Stoehr JD, Wenk GL (1998) Chronic neuroinflammation in rats reproduces components of the neurobiology of Alzheimer's disease. Brain Res 780, 294-303.
[134] Andrade C, Radhakrishnan R (2009) The prevention and treatment of cognitive decline and dementia: An overview of recent research on experimental treatments. Indian $J$ Psychiatry 51, 12-25.

[135] Rakesh G, Szabo ST, Alexopoulos GS, Zannas AS (2017) Strategies for dementia prevention: Latest evidence and implications. Ther Adv Chronic Dis 8, 121-136.

[136] Santos CY, Snyder PJ, Wu WC, Zhang M, Echeverria A, Alber J (2017) Pathophysiologic relationship between Alzheimer's disease, cerebrovascular disease, and cardiovascular risk: A review and synthesis. Alzheimers Dement (Amst) 7, 69-87. 